\title{
The role of Lactobacillus species in the control of Candida via biotrophic interactions
}

\author{
Isabella Zang| ${ }^{1}$, Ildiko-Julia Pap ${ }^{2}$, Christoph Aspöck ${ }^{2}$ and Christoph Schüller ${ }^{1,3, *}$ \\ ${ }^{1}$ University of Natural Resources and Life Sciences Vienna (BOKU), Department of Applied Genetics and Cell Biology (DAGZ), Tulln, \\ Austria. \\ ${ }^{2}$ University Hospital of St. Pölten, Institute for Hygiene and Microbiology, St Pölten, Austria. \\ ${ }^{3}$ Bioactive Microbial Metabolites (BiMM), BOKU, Tulln, Austria. \\ * Corresponding Author: \\ Christoph Schüller, University of Natural Resources and Life Sciences Vienna (BOKU), Department of Applied Genetics and Cell Biolo- \\ gy (DAGZ), UFT-Campus Tulln, Konrad-Lorenz-Straße 24, 3430 Tulln, Austria; phone: +43 147654 94184; \\ E-mail: christoph.schueller@boku.ac.at
}

\begin{abstract}
Microbial communities have an important role in health and disease. Candida spp. are ubiquitous commensals and sometimes opportunistic fungal pathogens of humans, colonizing mucosal surfaces of the genital, urinary, respiratory and gastrointestinal tracts and the oral cavity. They mainly cause local mucosal infections in immune competent individuals. However, in the case of an ineffective immune defense, Candida infections may become a serious threat. Lactobacillus spp. are part of the human microbiome and are natural competitors of Candida in the vaginal environment. Lactic acid, low $\mathrm{pH}$ and other secreted metabolites are environmental signals sensed by fungal species present in the microbiome. This review briefly discusses the ternary interaction between host, Lactobacillus species and Candida with regard to fungal infections and the potential antifungal and fungistatic effect of Lactobacillus species. Our understanding of these interactions is incomplete due to the variability of the involved species and isolates and the complexity of the human host.
\end{abstract}

doi: $10.15698 /$ mic2020.01.702

Received originally: 11.03.2019;

in revised form: 15.11.2019,

Accepted 20.11.2019,

Published 25.11.2019.

Keywords: Lactobacillus, Candida interaction, vaginal microbiome, probiotics.
Abbreviations:
$B V$ - bacterial vaginosis,
$C L R-C$-type lectin receptor,
EPS - extracellular polysaccharide, GM-CSF - granulocyte macrophage colony-stimulating factor IFN - interferon,
$L D H$ - lactate dehyrogenase,
NAC - non-albicans Candida,
$P M N$ - polymorphonuclear leukocyte,
$S N P$ - single nucleotide polymorphism,
$T L R$ - Toll-like receptor,
$V V C$ - vulvovaginal candidiasis.

\section{INTRODUCTION}

The composition of the complex microbial communities hosted by the human body is highly dependent on the environmental conditions and host factors. Thus, microbiome characteristics vary from site to site and also between individuals. Microbiomes play an important role in pathogen resistance, strengthening the immune system and nutrition uptake [1]. The mycobiome is a subset of the microbiome and reflects the load and composition of fungal cells in the human body [2]. The human vaginal microbiome is associated with prevention of various urogenital diseases such as, bacterial vaginosis, yeast and viral infections, sexually transmitted infections or urinary tract infections [3]. Lactobacillus spp. and Candida spp. are commensals of the hu- man microbiome [4]. Candida is also an opportunistic pathogen and can cause infections like vulvovaginal candidiasis (VVC), as well as more severe systemic infections. About $75 \%$ of women suffer from VVC at least once during their lifetime [5]. Systemic Candida infections occur in immunocompromised patients [6], caused by Candida albicans (about 50\%) and Candida glabrata (15\%-25\%) [7-9]. Lactobacillus spp. are part of the healthy vaginal microbiome and are seen as promising probiotics to treat or prevent mucosal Candida infections or to support traditional treatment options [10]. Probiotics are defined by the WHO as live microorganisms that, when administered or consumed in adequate quantities, confer health benefits [4]. Applying Lactobacillus to treat fungal infections is based on 
the premise that certain Lactobacillus species exert a protective effect in vivo by reducing the adhesion of the fungus to the vaginal mucosa $[11,12]$, production of organic acids $[11,13,14]$ and favorable metabolites [15-18] as well as enhancing vaginal epithelial cell immune defense mechanisms $[19,20]$.

Several articles discuss the composition of the human microbiome and mycobiome in detail [21-23] and its importance with regard to vaginal health $[24,25]$. The role of Lactobacillus species as general probiotics has been assessed previously [4, 26-28]. Here we focus on the molecules and mechanisms behind the putative interactions between Lactobacillus and Candida spp.

\section{HUMAN ASSOCIATED LACTOBACILLI}

Most vaginal microbiota contain Lactobacillus species [2931 , with quantity and proportion of specific species and strains varying between women of specific ethnic origins [24]. Alterations in this microbiome often lead to symptomatic conditions, for example bacterial vaginosis or other mucosal vaginal infections [25]. Changes in the quantity of vaginal microorganisms also play a role in septic postpartum, neonatal infections, pelvic inflammatory disease, miscarriage, pre-term birth and increased HIV acquisition and onward transmission [29]. Lactobacillus spp. are facultative anaerobe, gram-positive, catalase-negative, non-sporeforming rods. They can produce lactic acid as end product of homolactic fermentation [32]. About 200 species are associated with the Lactobacillus genus complex [33, 34]. Various Lactobacillus spp. are part of the normal human gastrointestinal and vaginal flora. However, the species involved differ between gastrointestinal (GI) and vaginal tract. In fact, Lactobacillus spp. are the predominant members of the vaginal microbiome in healthy women [26] and are thought to help preventing vaginal dysbiosis [35]. A healthy vaginal environment is often associated with a L. crispatus, L. gasseri and/or a $L$. jensenii dominated microbiome [36, 37]. Besides, there are also women with a microbiome consisting of higher proportions of facultative and anaerobe bacteria [3], including Prevotella or Gardnerella $[23,24]$. These non-Lactobacillus dominated microbiomes are also considered as a healthy, normal vaginal flora in asymptomatic women and are not necessarily a sign for disease.

One of the most frequently isolated organisms in the vaginal tract is $L$. iners. It is found in about $50 \%$ of both, healthy and diseased women, which is probably due to its high degree of adaption to the sometimes changing vaginal environment. $L$. iners has a small genome which indicates a parasitic or symbiotic lifestyle. It is associated with increased risk of vaginal dysbiosis [37]. A L. crispatus dominated microbiome is the second most common environment. Compared to $L$. iners and mixed vaginal microbiomes, dominance of $L$. crispatus is associated with a more stable microbiome and reduced probability to shift towards bacterial vaginosis [24]. Analysis at the species-level showed a shift from healthy vaginal microbiome dominated by L. crispatus to $L$. iners in genital infections such as VVC,
Chlamydia trachomatis and bacterial vaginosis [38]. The composition of the vaginal microbiome not only differs between individual women, but also by ethnicity $[23,24$, $37,39]$. With changing dominating bacteria, also the $\mathrm{pH}$ of the vaginal environment changes slightly. The lowest median $\mathrm{pH}$ was reached by a L. crispatus dominating microbiome $(\mathrm{pH} 4.0 \pm 0.3)$ and the highest $\mathrm{pH}$ was detected in women with a non-Lactobacillus dominated one $(\mathrm{pH} 5.3 \pm$ 0.6) [3]. The vaginal environment also fluctuates throughout the menstrual cycle. During menstruation a slight decrease in Lactobacillus spp. and a relative increase in other bacteria occur [24]. This may be explained by the fluctuation in estrogen levels, as high levels of estrogen may favor a Lactobacillus dominated environment [40]. Estrogen levels are low at the beginning of the menses, which could have a negative effect on Lactobacillus spp. numbers [24]. Preterm delivery is correlated with dysbiosis, lower vaginal levels of $L$. crispatus and higher levels of other taxa [41, 42]. Vitamin D level correlates with the vaginal L. crispatus abundance and could thus prevent pregnancy complications [43]. Following the conclusions of Hickey and colleagues it is surprising that since Döderlein's initial discovery and antibiotic activity of human associated lactic acid bacteria about 150 years ago, the microbial ecosystem of the human vagina is still not fully understood [23].

\section{HUMAN ASSOCIATED FUNGI}

Fungi contribute marginally to the human microbiome but nobody is fungus-free. In the gut, about $0.1 \%$ of the species are of fungal origin according to metagenomics studies [44, 45]. Nevertheless, fungi produce unique metabolites and enzymes and thus the fungal constituents may help maintaining microbial community structure, metabolic function and immune-priming frontiers [46]. A small number of fungal species are asymptomatic colonizers like Candida spp., Malassezia spp., Cryptococcus neoformans or Pneumocystis jirovecii. They have the potential to become pathogenic for example when the host is immunocompromised or the host environment is disturbed by antibiotic treatment [47]. Despite antifungal therapy they survive as persisters [48] or acquire transient antifungal resistance (heteroresistance) [49].

Candida spp. are the fourth most common cause of nosocomial systemic infections in the United States. $C$. albicans has the highest prevalence in humans [50]. It is part of the oral, gut and vaginal mucous microbiota and is associated with causing VVC $[10,47]$. Other relevant human associated species are $C$. glabrata, $C$. tropicalis, $C$. krusei, C. parapsilosis, C. dubliniensis and C. Iusitaniae [5153].

\section{Candida albicans}

C. albicans can be isolated in up to $80 \%$ of healthy individuals and has its natural habitat on skin and mucous membranes like oral or vaginal epithelium and urogenital tract [50]. C. albicans can colonize without symptoms host niches which differ in nutrient availability, $\mathrm{pH}$ or $\mathrm{CO}_{2}$ levels. Its ability to thrive in these conditions is an indication for its 
commensalism in humans and an important feature for its pathogenicity as well. C. albicans is pleomorphic and able to grow as yeast, as pseudohyphae cells or as true hyphae $[21,50,54]$. Pathogenicity is associated with invasive hyphal growth [55], whereas commensalism of C. albicans happens mostly in the adherent yeast cell form (also called blastospores), since epithelial cells fail to efficiently recognize them [54, 56]. C. albicans blastospores are associated with vaginal transmission [5]. C. albicans belongs to the CTG clade of Ascomycota and Saccharomycotina [57, 58] with many associated asexual species [59]. CTG addresses the reassignment of the conventional Leu CUG codon to serine $[60,61]$. The selective advantage of such as reassignment is speculative but might cause a higher variability of surface exposed proteins to adapt to environmental challenges such as recognition by the immune system [62].

C. albicans is the cause of most oral and vaginal Candidiasis [10]. Important key virulence factors of C. albicans include biofilm formation, countering host innate immunity, evasion from host immune system, adherence to host surface, yeast to hyphae transition and production of candidalysin [50, 54, 63]. Candidalysin is a cytolytic peptide toxin mainly expressed by hyphal cells that directly damages epithelial membranes leading to activation of a danger response signaling pathway and thus epithelial immunity [64]. Another important virulence factor is the ability to escape from phagocytosis by neutrophils (the major fungal killing effector immune cells) and macrophages. C. albicans escapes by inducing non-lytic expulsion, increasing the alkalinity, hyphae formation, generating protective antioxidants or induction of pyroptosis to lyse the phagocyte [50]

Furthermore, biofilm formation is important for pathogenicity and treatment, because biofilms, among other traits, exhibit higher antifungal resistance compared to planktonic cells. Only two classes of agents, amphotericin B and echinocandins were found to have an in vitro efficacy against fungal biofilms [65]. Additionally, mechanisms of the immune system against infections, such as macrophage migration towards $C$. albicans are reduced when cells are in a biofilm structure [66]. Biofilm formation in C. albicans develops in several stages. After initial adhesion and biofilm arrangement, the biofilm disperses $[67,68]$. These dispersed biofilm cells were shown to build more robust biofilms and exhibit a higher virulence [68]. Mixed species biofilms are the basis for intimate contacts and cross kingdom interactions between bacteria and fungi.

\section{Non-albicans Candida species}

Recent studies show that isolation of non-albicans Candida (NAC) species became more frequently isolated in the last two decades [69-72]. This is perhaps due to the better treatment and thus lower incidence of $C$. albicans. The most important strains associated with diseases are $C$. glabrata, C. tropicalis, C. krusei, C. dubliniensis and C. parapsilosis [73]. Susceptibility to antifungal drugs differs between the species. C. glabrata and C. krusei are intrinsically resistant to azoles, C. parapsilosis to echinocandins [74], and $C$. auris an emerging species is notably resistant to several drugs $[75,76]$.
C. glabrata, the most frequent isolated NAC species in Europe and North America, is isolated in around $10 \%$ of candidiasis patients $[70,73]$. C. glabrata is related to the bakers' yeast Saccharomyces cerevisiae [8], and belongs to the Nakaseomyces clade [77]. Similar to $S$. cerevisiae, C. glabrata grows only in yeast form. Detailed genomic analyses show the divergence of the $C$. glabrata isolates into several distinguishable clades and document remnants of occasional mating events [78-80]. Other human pathogenic Candida species like $C$. tropicalis or $C$. dubliniensis are closer related to $C$. albicans [81]. The phylogenetic distance of pathogenic Candida spp. suggests pathogenicity has evolved independently [9]. Human virulence of Candida species has developed in several independent ways and entails different mechanisms regarding adhesion, persistence, immune system evasion, stress resistance, and nutrient requirements [82-84]. C. glabrata has highly efficient adhesion to various surfaces due to a range of adhesins [85], high stress resistance and in addition has the shortest replication time of all Candida spp tested so far (our unpublished results) [86].

C. glabrata strains have an intrinsic resistance to azole antifungal drugs $[87,88]$. C. glabrata does not cause epithelial damage and does not provoke a strong immune response. Furthermore, it can reside in macrophages without immediately harming them [9]. C. glabrata does not form a biofilm on vaginal mucosa in a mouse model. However, it is able to form biofilms on abiotic surfaces such as medical devices such as vascular and urinary catheters [89, 90]. Biofilms on abiotic surfaces consist of yeast cells in multilayer structures [91]. Interestingly, a positive interaction between $C$. albicans and $C$. glabrata for host infection has been suggested. Mixed biofilms consisting of $C$. glabrata and $C$. albicans lead to more robust and complex structures and improve antifungal resistance [92]. We observed relatively frequent co-isolation of both fungi. Furthermore, C. albicans and C. glabrata co-infection seems also to be important for both initial colonization and establishment of oropharyngeal candidiasis infection by C. glabrata [93].

Other NCAs are such as the C. parapsilosis complex, C. tropicalis, are, with regional differences, of more or less of similar prevalence as C. glabrata, while $C$. dubliniensis, C. krusei and C. lusitaniae are less frequently isolated [88, 94]. In general, commensal and pathogenic Candida species are confronted with and are part of the microbiome. Thus, multiple interactions, either synergistic or antagonistic, with various bacterial species are common [95].

\section{VULVOVAGINALE CANDIDIASIS}

The most common classic mucosal vaginal infections include bacterial vaginosis (BV), Trichomoniasis and VVC [96]. VVC is an acute inflammatory disease and one distinguishes between the uncomplicated and complicated form [40]. Symptoms for both are acute pruritus, erythematous vulva, dyspareunia and white vaginal discharge, which makes both variants clinically indistinguishable [5]. Complicated VVC is defined as a recurrent infection or infections in pregnant, immunocompromised and debilitated persons, 
as well as infections caused by Candida species other than C. albicans [40]. Uncomplicated VVC comprises infections with $C$. albicans, non- recurrent infections and/or infections in an immunocompetent host [40]. Around $11-30 \%$ of VVC are induced by NAC species [6]. A recurrent form of VVC develops in about $5-8 \%$ of the cases $[5,97]$. Around $15 \%$ of recurrent VVC infections are induced by $C$. glabrata [40]. Diagnosis of vaginitis is normally conducted by microscopy, wet mount, culture or PCR $[96,98]$.

Treatment options for VVC comprise a variety of antifungal agents, e.g. fluconazole (oral), miconazole (topical) or clotrimazole (topical) [40]. Both, oral and topical antifungal agents are prescribed for 1 to 7 days, depending on dosage and drug [5]. Fluconazole is the preferred choice against fungal infections as it can be taken orally in single dose [5]. Complicated VVC often needs a more rigid regime in order to keep the vaginal fungal load at reduced levels [10]. In addition, some NAC species are intrinsically resistant or less susceptible $[10,99]$. In that case a broader spectrum agent like amphotericin B deoxycholate, voriconazole, or echinocandins, such as caspofungin and anidulafungin, can be used to treat the infection $[7,10]$. Infections caused by $C$. glabrata can also be treated alternatively with boric acid or flucytosine [100]. Acquired antimycotic resistance emerges mainly during treatment due to selection in patients and is usually confined and rarely transferred between patients [74]. Still, therapy improvements for species with antimycotic resistance are needed.

\section{METABOLIC BYPRODUCTS OF LACTOBACILLUS}

Commensal bacteria generate metabolic byproducts to support their persistence in the host and confer a survival advantage over invading pathogens [32]. Lactobacillus spp. produce lactic acid, acetic acid, $\mathrm{H}_{2} \mathrm{O}_{2}$, biosurfactants and other compounds (see Figure 1).

\section{Lactic Acid}

Lactobacilli produce different short chain aliphatic organic acids, like lactic acid or acetic acid. The content of acetic acid in the vaginal environment is low, ranging from 1-4 $\mathrm{mM}$ [101] as it is mainly produced under aerobic conditions and the vaginal environment is anaerobic or microaerobic. Indeed, acetate concentration may rise during BV [102]. Lactic acid, on the other hand, is produced through anaerobic respiration and is thought to decrease the $\mathrm{pH}$ in the vaginal tract $[12,103]$. Domination of the vaginal microflora by Lactobacillus spp. is accompanied by a low $\mathrm{pH}$ (pH 3.5 - 4.5) [104]. Lactic acid concentration in the vaginal milieu is around $110 \mathrm{mM}$ [104]. Lactic acid in combination with low $\mathrm{pH}$ was shown to inhibit $C$. albicans [105]. No inhibition of $C$. albicans $[14,17,106]$ or $C$. glabrata $[14,17$, 107] was observed at a lactic acid concentration reached with the supernatant of a cultured $L$. rhamnosus strain. The capability and rate of production of lactic acid is Lactobacillus strain specific. It was proposed that only elevated levels of lactic acid efficiently inhibit fungal growth $[13,107]$. In support of this, supernatants of L. rhamnosus, L. casei and L. acidophilus exhibit an antifungal effect against Candida spp. only if harvested after prolonged incubation ( $24 \mathrm{~h}$ or $48 \mathrm{~h}$ ) in which lactic acid could accumulated in the medium [13]. In addition, the reported lactic acid concentration of the vaginal tract was found to be too low to prevent growth of all relevant Candida species (our unpublished observation). However, in the local vaginal micro milieu or biofilm, in which higher concentrations of lactic acid could be reached, lactic acid could be a relevant antifungal agent. Also, low $\mathrm{pH}$ itself plays a minor role in Candida infections as the vaginal $\mathrm{pH}$ does not change during VVC in contrast to bacterial dysbiosis $[5,108]$. Most studies also show that Lactobacillus remains the dominant bacterial species during VVC $[108,109]$. The composition of the Lactobacillus

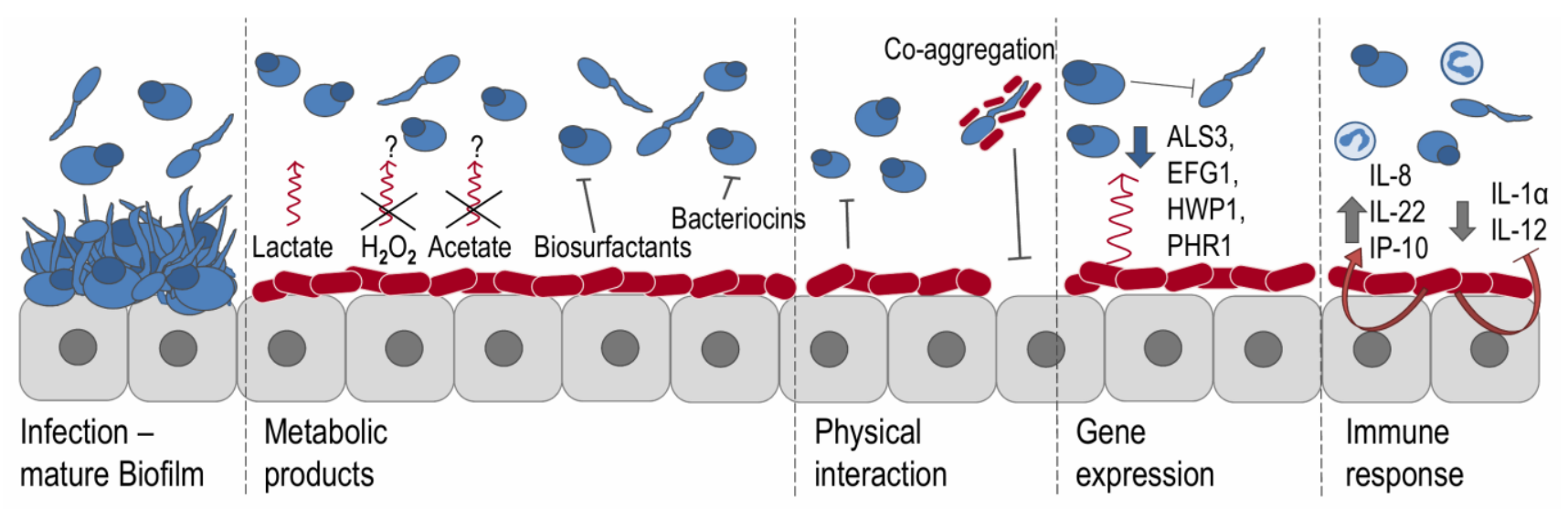

Yeast form Hyphal form Lactobacillus S) Granulocyte

FIGURE 1: Interactions between $\boldsymbol{C}$. albicans and Lactobacillus spp. Production of metabolic products prevent colonization through $C$. albicans either due to prevention of adhesion to the epithelial cell wall, or due to high concentrations of organic acids, exerting a fungistatic effect. $\mathrm{H}_{2} \mathrm{O}_{2}$ and acetate probably don't play a role in the vaginal tract. Saturation of adhesion sites and co-aggregation of Lactobacillus spp. prevent adherence of Candida spp. Gene expression in C. albicans gets changed due to presence of Lactobacillus. Expression of genes responsible for adherence and yeast to hyphal formation is reduced. Presence of Lactobacillus can alter the host immune response in case of Candida colonization to attract granulocytes and promote the immune defense. The picture was adapted from Bradford and Ravel[22]. 
strains differs during Candida infections [108, 110], which could lead to a decrease of lactic acid concentration and possibly other metabolites which in turn may allow Candida growth in the vaginal tract.

Stress response to weak organic acids like lactic acid differs between Candida species. A C. albicans transcriptome analysis of a set of different weak organic acids like lactic, acetic, propionic, and butyric acid led to a discovery of a complex core transcriptional response to all tested organic acids. In general, ribosomal RNA and RNA synthesis was reduced, indicating that $C$. albicans enters a starvation-like metabolic state after prolonged exposure to organic acids with reduced transcription, translation and growth. Furthermore, intracellular iron was decreased upon weak organic acid exposure [111]. Generally, exposure to weak acids leads to dramatic changes of gene expression. The involved pathways differ between species. For example, CaMig1, a transcription factor associated with glucose repression, was discovered as a central regulator of weak organic acid like lactic, acetic, propionic, and butyric acid resistance in $C$. albicans, however, it is only active in the presence of glucose [112]. In fact, glucose is limited in the vaginal tract [113], making this glucose-dependent response unlikely to contribute to lactic acid resistance in the vaginal environment. $\mathrm{Mnl1}$, the $C$. albicans homologue of the yeast Com2, was found to be required for acetic acid response [114]. In S. cerevisiae, the transcription factors Msn2, Msn4 and War1 signal weak acid stress (e.g. sorbic acid) $[115,116]$. Activation of War1 leads to expression of an $A B C$ (ATP binding cassette) transporter gene PDR12, which is required for weak acid ion efflux [115] and also induced during lactic acid stress in S. cerevisiae [117]. Interestingly, in $C$. glabrata the high osmolarity glycerol (HOG) pathway instead of the homologs CgMsn2 and CgMsn4 is activated by sorbic acid [116]. The C. glabrata HOG pathway is signaling general weak acid response and osmotic and oxidative stress [116]. Deletion of HOG1 in C. glabrata led to a susceptibility against lactic acid at physiological conditions. Therefore, HOG1 response is needed for resistance to lactic acid stress [118].

Lactic acid itself may indirectly support antifungal therapy. Lactic acid and acetic acid at physiological concentrations increase efficacy of different azoles against $C$. albicans. Higher concentrations also improved efficacy of azoles against $C$. glabrata [14]. Undissociated organic acids like for example lactic acid or acetic acid lead to perturbation of plasma membrane structures in yeast cells, which may increase uptake of azoles into the yeast cell [119]. The overall concentration of organic acids like acetic acid or lactic acid may be too low to have a fungistatic effect on their own. However, facilitating azole efficacy by lactic acid could improve traditional treatment of Candida infections.

Anyhow, outside of the host environment, lactic acid could be less important as antifungal agent. In a co-culture system with C. albicans, L. paracasei [120] and L. rhamnosus, L. casei and L. acidophilus [13] do not acidify the environment significantly. This could indicate that these isolates do not produce sufficient amount of lactic acid. However, in contrast to these studies we find consistently strong acidification in co-cultures of $C$. albicans, C. glabrata with $L$. fermentum, L. rhamnosus or $L$. gasseri in vitro (our unpublished observations). These differences could arise from the media used for co-culture. Whereas both studies used brain heart infusion (BHI) broth for their assays [13, 120], we used MRS, which favors Lactobacillus growth and is slightly acidic. Of note, $\mathrm{BHI}$ medium is buffered to a neutral $\mathrm{pH}$. C. albicans can utilize lactate as carbon source and can even form biofilms [121]. The Lactobacillus spp. generated lactate is used up by $C$. albicans as carbon source at neutral $\mathrm{pH}$, explaining why in these studies Lactobacillus did not acidify the neutral $\mathrm{BHI}$ medium. This notion is also supported by a study from Willems et al. [122] in which a Streptococcus mutans - $C$. albicans biofilm had a higher lactic acid production, accompanied with a higher $\mathrm{pH}$ compared to a sole bacterial biofilm, hinting that $C$. albicans uses the lactate and thus, prevents acidification of its environment.

Taken together, lactic acid is most probably not the sole antifungal agent produced by Lactobacillus spp. Neutralized supernatants of $L$. pentosus $[123,124]$, L. rhamnosus $G R-1$ and L. reuteri $R C-14$ [11] were able to inhibit growth of $C$. albicans [123, 124] and C. glabrata [11]. In support of this, inhibition of Candida spp. by L. crispatus, L. gasseri and L. vaginalis is not correlated to lactic acid production [125].

\section{Hydrogen Peroxide}

Production of $\mathrm{H}_{2} \mathrm{O}_{2}$ is an important feature of Lactobacillus spp. to defend against bacterial infections $[109,126]$. This is probably not strictly the case for Candida infections. The non- $\mathrm{H}_{2} \mathrm{O}_{2}$ producer $L$. rhamnosus $\mathrm{GR}-1$ and the $\mathrm{H}_{2} \mathrm{O}_{2}$ producer $L$. reuteri RC-14 both inhibited growth of $C$. albicans [105]. Similar results were obtained with C. glabrata [11]. Most isolates of $C$. glabrata also have high tolerance to reactive oxygen species (ROS) such as $\mathrm{H}_{2} \mathrm{O}_{2}$ [127]. Several facts suggest that $\mathrm{H}_{2} \mathrm{O}_{2}$ only plays a minor role in Candida defense of Lactobacillus species in the microaerobic vaginal environment. Lactobacillus spp. produce $\mathrm{H}_{2} \mathrm{O}_{2}$ predominantly under aerobic conditions, but the conditions in the vagina are hypoxic [27]. The physiological concentration reached in Lactobacillus cultures $(<100 \mu \mathrm{M})$ does not harm lactobacilli, BV - associated bacteria and Candida spp. [128]. High concentrations of $\mathrm{H}_{2} \mathrm{O}_{2}(10 \mathrm{mM})$ which could harm Candida spp. were shown to be harmful to vaginal Lactobacillus species [128].

\section{Other antifungal factors}

Other suggested antifungal factors produced by bacteria are small molecules like bacteriocins and biosurfactants [129]. Bacteriocins are proteinaceous, bacterial substances, which are able to inhibit growth of same or closely related species. Bacteriocin-like substances are very similar to bacteriocins, but often inhibit a broader range of species like gram-positive, gram-negative bacteria or fungi [130]. Pentocin TV35b is a bacteriocin-like peptide produced by L. pentosus which was found to have a fungistatic effect on C. albicans [18]. It remains the only reported bacteriocinlike peptide till today. 
Adhesion to the mucosa is generally seen as the first step of infection [131, 132]. Lactobacillus spp. produce biosurfactants reducing adherence of competing organisms to the epithelial cell wall [133]. Some biosurfactants are active against $C$. albicans $[15,98]$. For example, biosurfactants produced by $L$. jensenii and $L$. gasseri are able to reduce biofilms on polystyrene plates of $C$. albicans, $C$. tropicalis and C. krusei by 25\%-35 [15]. CV8LAC, a biosurfactant produced by $L$. brevis is able to decrease $C$. albicans adhesion and biofilm formation to precoated medical-grade silicone [134]. The use of this biosurfactants could be developed further as a potential new coating material for medical devices to minimize Candida infections [134]. In general, supernatants of different Lactobacillus species were found to reduce adhesion of $C$. albicans to HeLa cells (L. crispatus, L. gasseri) [125], to plastic surface (L. paracasei) [135], as well as to TR146 cells (L. rhamnosus) [136]. The question remains open, if these supernatants contain unrecognized biosurfactants or if other metabolites are able to reduce adhesion.

C. albicans adheres to vaginal epithelial cells and initiates morphological changes of the cells leading to induction of cellular endocytosis. Treating these infected cells with $L$. crispatus lead to a decrease in adhesion, hyphal formation and proliferation of Candida [137]. C. albicans adhesion to Vk2/E6E7 cells was reduced by their preincubation with extracellular polysaccharide (EPS) produced by L. crispatus L1 [16]. This reduction was similar to the celldependent reduction of adhesion by a preincubated L. crispatus L1 [16]. However, co-cultivation of EPS and C. albicans on Vk2/E6E7 cells did not reduce adhesion of C. albicans, whereas co-culture of C. albicans and L. crispatus lead to a reduction of adhesion of $C$. albicans [16]. EPS could therefore be a putative new coating agent. The celldependent reduction of adhesion is probably due to coaggregation of Lactobacillus and Candida species. Coaggregation is a characteristic of early biofilm formation as it involves adhesion-receptor interactions between the microbial cell surfaces. Therefore, competition for binding sites could be partly influencing proper adhesion of Candida to mucosal surfaces [12]. With regard to studies with NAC species, L. reuteri [12], L. pentosus [123] L. rhamnosus GR-1 and L. reuteri RC-14 [11] were shown to possess the ability to co-aggregate with various Candida species besides C. albicans, for example C. glabrata $[11,12]$, C. krusei [12] or C. tropicalis [123]. Interestingly, good initial adhesion of L. gasseri, L. crispatus or L. vaginalis isolates was not consistent with good inhibition of adherence of $C$. albicans [125]. This suggests that minimizing the adhesion of C. albicans is not solely due to saturation of adhesion sites, but rather through either changes in the epithelial cell surface or due to influencing the adhesion ability of the pathogen itself [125].

Lactobacillus spp. influence C. albicans morphology. Hyphae formation was impaired in co-culture with $L$. paracasei $[120,135]$. Interaction of Lactobacillus and C. albicans alters the gene expression pattern towards the yeast form. C. albicans yeast form generally shows reduced adhesion and biofilm formation [54]. Interaction between Lactobacil- lus spp. and Candida leads to expression changes of genes associated with biofilm formation, yeast to hyphal transition and adhesion. For example, ALS3, EFG1 or HWP1, were suppressed in $C$. albicans cells treated with $L$. paracasei supernatant $[135,138]$. Efg1 is a regulator for several genes responsible for yeast-hyphae transition such as ALS3, HWP1 or SAP (secreted aspartate proteases) genes [139, 140]. Furthermore, interaction with $L$. paracasei induced expression of $Y W P 1$, a gene associated with the yeast form [135]. Furthermore, PHR1, a pH responsive gene coding for a glucan remodeling enzyme supporting hyphal growth in Candida, was downregulated in C. albicans co-cultured with L. reuteri RC-14 and L. rhamnosus GR-1 [105, 141]. This suggests that Lactobacillus spp. influences $C$. albicans to stay in its less invasive form, which could help preventing overgrowth of the fungus. In addition, the interaction directly leads to downregulation of several C. albicans genes related to adhesion, invasion and counteraction of host defenses [138]. In C. glabrata altered gene expression of genes related to adhesion in the presence of $L$. rhamnosus and $L$. reuteri supernatants was also observed. Downregulation of the adhesion gene YAK1 was accompanied by reduced levels of the Yak1-dependent adhesin EPA6, which is involved in adhesion and biofilm development [107, 142]. This indicates that presence of Lactobacillus spp. decreases adhesion and maybe virulence of $C$. glabrata.

RNA-Seq of $C$. albicans gene expression in response to a TR146 cell monolayer, which was preincubated with L. rhamnosus $G G$ revealed upregulation of genes involved in fatty acid catabolism, glyoxylate cycle and gluconeogenesis and downregulation of glycolysis and ergosterol biosynthesis genes [136]. Another study investigating L. reuteri RC-14 and L. rhamnosus GR-1 co-culture found an upregulation of glycolysis and a reduced expression of genes relating to gluconeogenesis [105]. Thus, strainspecific effects are obviously an important factor to keep in mind while exploring Lactobacillus spp. as potent novel probiotics. Furthermore, one study was conducted on cell layer surface, while the other one on an abiotic surface $[105,136]$. This could be an indicator for the importance of proper in vitro systems, mimicking the actual environment as close as possible.

\section{Three-way interactions including the host}

The ability to recognize and sense a pathogen is crucial for the immune system to initiate an immune response. Candida spp. have a cell wall, consisting of carbohydrate polymers such as mannans, $\beta$-glucans and chitin merged with a protein matrix [143]. This cell wall components can be detected by Toll-like receptor family (TLR), C-type lectin receptor (CLRs) family like Dectin-1, Dectin-2 or Mincle, Galectin-3 and scavenger receptors [143] which start the immune response. For example, $C$. albicans mannans gets recognized by TLR4, whereas $\beta$ - glucans are sensed by Dectin-1 [143]. CLRs are the responsible receptor family for the immune reaction against disseminated Candidiasis [144] CBL-B, an E3-ubiquitin ligase, controls availability of Dectin1 and -2 receptors in phagocytes [144]. Interestingly, in vivo testing in mice showed that inhibition of CBL-B con- 
veys a protective effect against $C$. albicans systemic infections [144]. Single nucleotide polymorphism (SNP) in different TLRs also can lead to increased susceptibility against C. albicans and Candidiasis, for example SNP in TLR1 is associated with an impaired cytokine release during $C$. albicans infection [143].

Activation of the host innate immune response by C. albicans leads to the production of various cytokines and chemokines by epithelial cells [145]. An effective Th1 response is crucial for defense against $C$. albicans infections $[20,145,146]$. Development of antifungal Th1 response is initiated by TLRs [143]. Th2-type response, on the other hand, is considered as nonprotective against the fungi [147, 148]. Th1 response comprises production of INF- $\gamma$, TNF $\beta$ IL- 6 and IL-2, which are protective against most fungal infections [149]. Humoral immunity is mediated by Th2 response, which produce IL-4, IL-5 and IL-13 [150]. Upregulation of Th2 response is associated with reduced IFN- $\gamma$ production and therefore, correlating with higher disease severity and poor prognosis [149]. Th2 induction was found to be dependent on Type 1 interferon (INF-1) cytokines [151]. INF-1 are associated with mediation of lethal effects during disseminated Candida infections [152], which could be another explanation why Th2 response correlates with poor disease progression. Additionally, there are Th17 cells which, among others, produce IL-17. Th17 cytokines are thought to exhibit a protective role against mucosal and disseminated fungal infections [149]. Sole C. albicans interaction leads to a decrease of IL-2 and IL-4 production in epithelial cells. In addition, IL-17 response gets impaired, which suggests a diminished inflammatory immune response [137]. Furthermore, C. albicans hyphae bind to TLR2 and induce the production of IL-10, an antiinflammatory cytokine, which leads to fewer regulatory T cells [153] and therefore a decreased host immune response. In mice, IL-10 expression is associated with higher susceptibility to candidiasis [154, 155]. IL-8 and IL-1 $\alpha$ secretion gets significantly increased upon $C$. albicans treatment indicating that they play an important role in the natural host's defense against the yeast infection [19].

Treatment of epithelial cells with only Lactobacillus spp. also alters the immune response. For example, L. crispatus increased IL-2 and decreased IL-8 response of vaginal epithelial cells [137]. Another study found that stimulation of epithelial cells with L. rhamnosus GG or L. reuteri RC-14 without prior interaction with Candida leads to an upregulation of IL-8 release $[19,136]$. Treated cells showed neither visible damage [136] nor induction of apoptosis [156]. IL-8 acts as chemoattractant for polymorphonuclear leukocytes (PMNs) and other granulocytes. PMNs are associated with defense mechanisms against Candida infections [157]. Additionally, they induce a Th1 response [20]. Therefore, induction of IL-8 by Lactobacillus spp. could work as a protective mechanism for the host by attracting PMNs to quicken the immune response in case of an infection.

Simultaneous treatment of epithelial cells with C. albicans and Lactobacillus supernatants showed increased IL-8 (L. reuteri RC-14) and IFNY-induced protein 10 (IP-10) ( $L$. rhamnosus GR-1) release and reduced the inflammatory response of the host [19]. However, other studies showed that $L$. plantarum 59 and $L$. fermentum interaction downregulates IL-8 response in C. albicans infection on HeLa cells [158]. Quantity of antifungal agents produced by Lactobacillus spp. like lactic acid could in turn lead to a variance in cytokine response [19]. Treatment with L. crispatus was able to mitigate $C$. albicans-induced reduction in IL-17 expression of vaginal epithelial cells [137]. This would indicate that $L$. crispatus prevents $C$. albicans from downregulating an IL-17 dependent immune response. However, the role of Th17 response in VVC is not fully clear yet [159, 160]. Cells preincubated with $L$. rhamnosus have decreased release of lactate dehydrogenase (LDH) during infections [136]. LDH is a soluble enzyme, found in almost every living human cell and is responsible for lactic acid fermentation. In case the cell membrane is damaged, it is released into their surrounding extracellular space and serves as a cell death marker [161]. Decreased release of LDH suggests that cells, treated with Lactobacillus spp., are protected from C. albicans induced cell damage [136]. Another way how Lactobacillus spp. could mediate tolerance to $C$. albicans on the mucosa is by producing tryptophan catabolites via Indolamin-2,3-Dioxygenase IDO1 [162]. These act on regulatory $\mathrm{T}$-cells which results in raising local expression of IL-22 and thus, could provide immunoprotection to VVC. IDO1 and IL-22 deficiency in animals is linked to increased susceptibility in VVC [163].

The host immune response in C. glabrata infection is generally lower than with $C$. albicans [164]. It was shown that only granulocyte macrophage colony-stimulating factor (GM-CSF) is induced by C. glabrata. GM-CSF is a potent activator of macrophages and initiates recruitment of macrophages [164]. Since $C$. glabrata has the ability to survive and replicate in macrophages, it could be that the fungus attracts macrophages on purpose [164]. There are no studies addressing the immune response towards $C$. glabrata or other NAC species in presence of Lactobacillus spp.

Interestingly, treatment of vaginal cells with lactic acid (33 mM) decreases the production of IL-6 and IL-8 and significantly increases production of the anti-inflammatory cytokine IL-1 receptor antagonist (IL-1RA) which reduces the inflammatory activity of IL-1 $\alpha$ and IL-1 $\beta$ [165]. This suggests that lactic acid alone is sufficient to decrease production of pro-inflammatory molecules. However, it is currently unclear if this repression can be obtained when treating the cells with Candida and lactic acid simultaneously.

\section{CONCLUSION}

Lactobacillus species are promising candidates to improve treatment of vulvovaginal Candida infections. Results often vary between Lactobacillus and Candida strains, making it difficult to pinpoint specific pathways and mechanisms. The probiotic effect seen in vitro of Lactobacillus strains is probably only partly due to the accumulation of lactic acid. The lactic acid content in the vaginal tract is too low to have an effect on Candida spp. and one has to assume that higher local concentrations of lactic acid are possibly preventing overgrowth of Candida spp. in close proximity to 
Lactobacillus. In addition, organic acids produced by Lactobacillus spp. do positively influence efficacy of antifungal agents by increasing the permeability of fungal plasma membrane structure, which facilitates azole uptake. Still, lactic acid, low $\mathrm{pH}$ and, to a minor extent, other secreted metabolites are environmental signals sensed by $C$. albicans and are leading to changes of gene expression and transition to hyphal growth. Another putative mechanism for the probiotic effect might be competition for available niches and reduced adhesion. All in all, the antifungal effect (Figure 1) of Lactobacillus comprises different aspects and has a species and strain dependent components. So far most studies concentrated on C. albicans. However, NAC species have usually different resistance profiles and may also require different treatments. Moreover, studies addressing these fungi are still scarce. Further investigations are definitely needed to expand our knowledge on NACLactobacillus interactions. All in all, carefully selected Lactobacillus species active against specific Candida species could lead to improved treatment options.

\section{ACKNOWLEDGMENTS}

We thank the anonymous referees for their constructive comments and C. Gregori for critical reading of the manuscript. The work was supported by a grant of the Niederösterreichische Forschungs- und Bildungsges.m.b.H. LSC16016 to CS and CA. The Bioactive Microbial Metabolites facility (BiMM) is supported by a grant of the Niederösterreichische Forschungs- und Bildungsges.m.b.H (NfB) (K3-G2/026-2013).

\section{CONFLICT OF INTEREST}

The authors declare that there is no conflict of interest.

\section{COPYRIGHT}

(C) 2019 Zangl et al. This is an open-access article released under the terms of the Creative Commons Attribution (CC BY) license, which allows the unrestricted use, distribution, and reproduction in any medium, provided the original author and source are acknowledged.

Please cite this article as: Isabella Zangl, Ildiko-Julia Pap, Christoph Aspöck and Christoph Schüller (2019). The role of Lactobacillus species in the control of Candida via biotrophic interactions. Microbial Cell 7(1): 1-14. doi: 10.15698/mic2020.01.702

10. Sobel JD (2016). Recurrent vulvovaginal candidiasis. Am J Obstet Gynecol 214(1): 15-21. doi: 10.1016/j.ajog.2015.06.067

11. Chew SY, Cheah YK, Seow HF, Sandai D, Than LT (2015). Probiotic Lactobacillus rhamnosus GR-1 and Lactobacillus reuteri RC-14 exhibit strong antifungal effects against vulvovaginal candidiasis-causing Candida glabrata isolates. J Appl Microbiol 118(5): 1180-1190. doi: 10.1111/jam.12772

12. Jorgensen MR, Kragelund C, Jensen PO, Keller MK, Twetman S (2017). Probiotic Lactobacillus reuteri has antifungal effects on oral Candida species in vitro. J Oral Microbiol 9(1): 1274582. doi: 10.1080/20002297.2016.1274582

13. Matsubara VH, Wang Y, Bandara HM, Mayer MP, Samaranayake LP (2016). Probiotic lactobacilli inhibit early stages of Candida albicans biofilm development by reducing their growth, cell adhesion, and filamentation. Appl Microbiol Biotechnol 100(14): 6415-6426. doi: 10.1007/s00253-016-7527-3

14. Lourenco A, Pedro NA, Salazar SB, Mira NP (2018). Effect of Acetic Acid and Lactic Acid at Low pH in Growth and Azole Resistance of Candida albicans and Candida glabrata. Front Microbiol 9: 3265. doi: 10.3389/fmicb.2018.03265

15. Morais IMC, Cordeiro AL, Teixeira GS, Domingues VS, Nardi RMD, Monteiro AS, Alves RJ, Siqueira EP, Santos VL (2017). Biological and physicochemical properties of biosurfactants produced by Lactobacillus jensenii $\mathrm{P}_{6 \mathrm{~A}}$ and Lactobacillus gasseri $\mathrm{P}_{65}$. Microb Cell Fact 16(1): 155. doi: 10.1186/s12934-017-0769-7

16. Donnarumma G, Molinaro A, Cimini D, De Castro C, Valli V, De Gregorio V, De Rosa M, Schiraldi C (2014). Lactobacillus crispatus L1: high cell density cultivation and exopolysaccharide structure characterization to highlight potentially beneficial effects against vaginal pathogens. BMC Microbiol 14(137. doi: 10.1186/1471-218014-137 
17. Allonsius $\mathrm{CN}$, van den Broek MFL, De Boeck I, Kiekens $\mathrm{S}$, Oerlemans EFM, Kiekens F, Foubert K, Vandenheuvel D, Cos P, Delputte P, Lebeer S (2017). Interplay between Lactobacillus rhamnosus GG and Candida and the involvement of exopolysaccharides. Microb Biotechnol 10(6): 1753-1763. doi: 10.1111/1751-7915.12799

18. Okkers DJ, Dicks LM, Silvester M, Joubert JJ, Odendaal HJ (1999). Characterization of pentocin TV35b, a bacteriocin-like peptide isolated from Lactobacillus pentosus with a fungistatic effect on Candida albicans. J Appl Microbiol 87(5): 726-734. doi: 10.1046/j.13652672.1999.00918.x

19. Martinez RC, Seney SL, Summers KL, Nomizo A, De Martinis EC, Reid G (2009). Effect of Lactobacillus rhamnosus GR-1 and Lactobacillus reuteri RC-14 on the ability of Candida albicans to infect cells and induce inflammation. Microbiol Immunol 53(9): 487-495. doi: 10.1111/j.1348-0421.2009.00154.x

20. Schaller M, Boeld U, Oberbauer S, Hamm G, Hube B, Korting HC (2004). Polymorphonuclear leukocytes (PMNs) induce protective Th1type cytokine epithelial responses in an in vitro model of oral candidosis. Microbiology 150(Pt 9): 2807-2813. doi: 10.1099/mic.0.27169-0

21. Underhill DM, Iliev ID (2014). The mycobiota: interactions between commensal fungi and the host immune system. Nat Rev Immunol 14(6): 405-416. doi: 10.1038/nri3684

22. Bradford LL, Ravel J (2017). The vaginal mycobiome: A contemporary perspective on fungi in women's health and diseases. Virulence 8(3): 342-351. doi: 10.1080/21505594.2016.1237332

23. Hickey RJ, Zhou X, Pierson JD, Ravel J, Forney LJ (2012). Understanding vaginal microbiome complexity from an ecological perspective. Transl Res 160(4): 267-282. doi: 10.1016/j.trsl.2012.02.008

24. Green KA, Zarek SM, Catherino WH (2015). Gynecologic health and disease in relation to the microbiome of the female reproductive tract. Fertil Steril 104(6): 1351-1357. doi: 10.1016/j.fertnstert.2015.10.010

25. van de Wijgert J, Jespers $V$ (2017). The global health impact of vaginal dysbiosis. Res Microbiol 168(9-10): 859-864. doi: 10.1016/j.resmic.2017.02.003

26. Borges S, Silva J, Teixeira P (2014). The role of lactobacilli and probiotics in maintaining vaginal health. Arch Gynecol Obstet 289(3): 479-489. doi: 10.1007/s00404-013-3064-9

27. Tachedjian G, Aldunate M, Bradshaw CS, Cone RA (2017). The role of lactic acid production by probiotic Lactobacillus species in vaginal health. Res Microbiol 168(9-10): 782-792. doi: 10.1016/j.resmic.2017.04.001

28. Amabebe E, Anumba DOC (2018). The Vaginal Microenvironment: The Physiologic Role of Lactobacilli. Front Med 5:181. doi: 10.3389/fmed.2018.00181

29. van de Wijgert JH, Borgdorff $H$, Verhelst $R$, Crucitti T, Francis $S$, Verstraelen $H$, Jespers $V$ (2014). The vaginal microbiota: what have we learned after a decade of molecular characterization? PLoS One 9(8): e105998. doi: 10.1371/journal.pone.0105998

30. Gevers D, Knight R, Petrosino JF, Huang K, McGuire AL, Birren BW, Nelson KE, White O, Methe BA, Huttenhower C (2012). The Human Microbiome Project: a community resource for the healthy human microbiome. PLoS Biol 10(8): e1001377. doi: 10.1371/journal.pbio.1001377

31. Srinivasan S, Hoffman NG, Morgan MT, Matsen FA, Fiedler TL, Hall RW, Ross FJ, McCoy CO, Bumgarner R, Marrazzo JM, Fredricks DN (2012). Bacterial communities in women with bacterial vaginosis: high resolution phylogenetic analyses reveal relationships of microbiota to clinical criteria. PLoS One 7(6): e37818. doi: 10.1371/journal.pone.0037818

32. Lebeer S, Vanderleyden J, De Keersmaecker SC (2008). Genes and molecules of lactobacilli supporting probiotic action. Microbiol Mol Biol Rev 72(4): 728-764, Table of Contents. doi: 10.1128/MMBR.00017-08

33. Goldstein EJ, Tyrrell KL, Citron DM (2015). Lactobacillus species: taxonomic complexity and controversial susceptibilities. Clin Infect Dis 60 (Suppl 2): S98-107. doi: 10.1093/cid/civ072

34. Wittouck S, Wuyts S, Meehan CJ, van Noort V, Lebeer S (2019). A Genome-Based Species Taxonomy of the Lactobacillus Genus Complex. mSystems 4(5): e00264-19. doi: 10.1128/mSystems.00264-19

35. Boris S, Barbes C (2000). Role played by lactobacilli in controlling the population of vaginal pathogens. Microbes Infect 2(5): 543-546. doi: 10.1016/s1286-4579(00)00313-0

36. Burton JP, Cadieux PA, Reid G (2003). Improved understanding of the bacterial vaginal microbiota of women before and after probiotic instillation. Appl Environ Microbiol 69(1): 97-101. doi: 10.1128/aem.69.1.97-101.2003

37. Petrova MI, Reid G, Vaneechoutte M, Lebeer S (2017). Lactobacillus iners: Friend or Foe? Trends Microbiol 25(3): 182-191. doi: 10.1016/j.tim.2016.11.007

38. Ceccarani C, Foschi C, Parolin C, D'Antuono A, Gaspari V, Consolandi C, Laghi L, Camboni T, Vitali B, Severgnini M, Marangoni A (2019). Diversity of vaginal microbiome and metabolome during genital infections. Sci Rep 9(1): 14095. doi: 10.1038/s41598-01950410-x

39. Fettweis JM, Brooks JP, Serrano MG, Sheth NU, Girerd PH, Edwards DJ, Strauss JF, The Vaginal Microbiome C, Jefferson KK, Buck GA (2014). Differences in vaginal microbiome in African American women versus women of European ancestry. Microbiology 160(Pt 10): 2272-2282. doi: 10.1099/mic.0.081034-0

40. Eckert LO (2006). Clinical practice. Acute vulvovaginitis. N Engl J Med 355(12): 1244-1252. doi: 10.1056/NEJMcp053720

41. Fettweis JM, Serrano MG, Brooks JP, Edwards DJ, Girerd PH, Parikh HI, Huang B, Arodz TJ, Edupuganti L, Glascock AL, Xu J, Jimenez NR, Vivadelli SC, Fong SS, Sheth NU, Jean S, Lee V, Bokhari YA, Lara AM, Mistry SD, Duckworth RA, 3rd, Bradley SP, Koparde VN, Orenda XV, Milton SH, Rozycki SK, Matveyev AV, Wright ML, Huzurbazar SV Jackson EM, et al. (2019). The vaginal microbiome and preterm birth. Nat Med 25(6): 1012-1021. doi: 10.1038/s41591-019-0450-2

42. Brown RG, Marchesi JR, Lee YS, Smith A, Lehne B, Kindinger LM Terzidou V, Holmes E, Nicholson JK, Bennett PR, Maclntyre DA (2018). Vaginal dysbiosis increases risk of preterm fetal membrane rupture, neonatal sepsis and is exacerbated by erythromycin. BMC Med 16(1): 9. doi: 10.1186/s12916-017-0999-x

43. Jefferson KK, Parikh HI, Garcia EM, Edwards DJ, Serrano MG, Hewison M, Shary JR, Powell AM, Hollis BW, Fettweis JM, Strauss lii JF, Buck GA, Wagner CL (2019). Relationship between vitamin D status and the vaginal microbiome during pregnancy. J Perinatol 39(6): 824836. doi: 10.1038/s41372-019-0343-8

44. Qin J, Li R, Raes J, Arumugam M, Burgdorf KS, Manichanh C, Nielsen T, Pons N, Levenez F, Yamada T, Mende DR, Li J, Xu J, Li S, Li D, Cao J, Wang $B$, Liang $H$, Zheng $H$, Xie $Y$, Tap J, Lepage $P$, Bertalan $M$, Batto JM, Hansen T, Le Paslier D, Linneberg A, Nielsen HB, Pelletier E, Renault $P$, et al. (2010). A human gut microbial gene catalogue established by metagenomic sequencing. Nature 464(7285): 59-65. doi: $10.1038 /$ nature08821

45. Arumugam M, Raes J, Pelletier E, Le Paslier D, Yamada T, Mende DR, Fernandes GR, Tap J, Bruls T, Batto JM, Bertalan M, Borruel N, Casellas F, Fernandez L, Gautier L, Hansen T, Hattori M, Hayashi T, 
Kleerebezem M, Kurokawa K, Leclerc M, Levenez F, Manichanh C, Nielsen HB, Nielsen T, Pons N, Poulain J, Qin J, Sicheritz-Ponten T, Tims $S$, et al. (2011). Enterotypes of the human gut microbiome. Nature 473(7346): 174-180. doi: 10.1038/nature09944

46. Seed PC (2014). The human mycobiome. Cold Spring Harb Perspect Med 5(5): a019810. doi: 10.1101/cshperspect.a019810

47. Huffnagle GB, Noverr MC (2013). The emerging world of the fungal microbiome. Trends Microbiol 21(7): 334-341. doi: 10.1016/j.tim.2013.04.002

48. Wuyts J, Van Dijck P, Holtappels M (2018). Fungal persister cells: The basis for recalcitrant infections? PLoS Pathog 14(10): e1007301. doi: 10.1371/journal.ppat.1007301

49. Ben-Ami R, Zimmerman O, Finn T, Amit S, Novikov A, Wertheimer $\mathrm{N}$, Lurie-Weinberger M, Berman J (2016). Heteroresistance to Fluconazole Is a Continuously Distributed Phenotype among Candida glabrata Clinical Strains Associated with In Vivo Persistence. mBio 7(4): e00655-16. doi: 10.1128/mBio.00655-16

50. da Silva Dantas A, Lee KK, Raziunaite I, Schaefer K, Wagener J, Yadav B, Gow NA (2016). Cell biology of Candida albicans-host interactions. Curr Opin Microbiol 34: 111-118. doi: 10.1016/j.mib.2016.08.006

51. Fornari G, Vicente VA, Gomes RR, Muro MD, Pinheiro RL, Ferrari C, Herkert PF, Takimura M, Carvalho NS, Queiroz-Telles F (2016). Susceptibility and molecular characterization of Candida species from patients with vulvovaginitis. Braz J Microbiol 47(2): 373-380. doi: 10.1016/j.bjm.2016.01.005

52. Turner SA, Butler G (2014). The Candida pathogenic species complex. Cold Spring Harb Perspect Med 4(9): a019778. doi: 10.1101/cshperspect.a019778

53. Silva S, Negri M, Henriques M, Oliveira R, Williams DW, Azeredo J (2012). Candida glabrata, Candida parapsilosis and Candida tropicalis: biology, epidemiology, pathogenicity and antifungal resistance. FEMS Microbiol Rev 36(2): 288-305. doi: 10.1111/j.1574-6976.2011.00278.x

54. Hall RA, Noverr MC (2017). Fungal interactions with the human host: exploring the spectrum of symbiosis. Curr Opin Microbiol 40: 58-64. doi: 10.1016/j.mib.2017.10.020

55. Cassone A (2015). Vulvovaginal Candida albicans infections: pathogenesis, immunity and vaccine prospects. BJOG 122(6): 785-794. doi: 10.1111/1471-0528.12994

56. Pande K, Chen C, Noble SM (2013). Passage through the mammalian gut triggers a phenotypic switch that promotes Candida albicans commensalism. Nat Genet 45(9): 1088-1091. doi: $10.1038 / \mathrm{ng} .2710$

57. Ebersberger I, de Matos Simoes R, Kupczok A, Gube M, Kothe E, Voigt $K$, von Haeseler A (2012). A consistent phylogenetic backbone for the fungi. Mol Biol Evol 29(5): 1319-1334. doi: $10.1093 / \mathrm{molbev} / \mathrm{msr} 285$

58. Spatafora JW, Aime MC, Grigoriev IV, Martin F, Stajich JE, Blackwell M (2017). The Fungal Tree of Life: from Molecular Systematics to Genome-Scale Phylogenies. Microbiol Spectr 5(5). doi: 10.1128/microbiolspec.FUNK-0053-2016

59. Daniel HM, Lachance MA, Kurtzman CP (2014). On the reclassification of species assigned to Candida and other anamorphic ascomycetous yeast genera based on phylogenetic circumscription. Antonie Van Leeuwenhoek 106(1): 67-84. doi: 10.1007/s10482-0140170-z

60. Kollmar M, Muhlhausen S (2017). Nuclear codon reassignments in the genomics era and mechanisms behind their evolution. BioEssays 39(5). doi: 10.1002/bies.201600221
61. Mateus DD, Paredes JA, Espanol Y, Ribas de Pouplana L, Moura GR, Santos MA (2013). Molecular reconstruction of a fungal genetic code alteration. RNA Biol 10(6): 969-980. doi: 10.4161/rna.24683

62. Santos MA, Ueda T, Watanabe K, Tuite MF (1997). The nonstandard genetic code of Candida spp.: an evolving genetic code or a novel mechanism for adaptation? Mol Microbiol 26(3): 423-431. doi: 10.1046/j.1365-2958.1997.5891961.x

63. de Groot PW, Bader O, de Boer AD, Weig M, Chauhan N (2013). Adhesins in human fungal pathogens: glue with plenty of stick. Eukaryot Cell 12(4): 470-481. doi: 10.1128/EC.00364-12

64. Moyes DL, Wilson D, Richardson JP, Mogavero S, Tang SX, Wernecke J, Hofs S, Gratacap RL, Robbins J, Runglall M, Murciano C, Blagojevic M, Thavaraj S, Forster TM, Hebecker B, Kasper L, Vizcay G lancu SI, Kichik N, Hader A, Kurzai O, Luo T, Kruger T, Kniemeyer O, Cota E, Bader O, Wheeler RT, Gutsmann T, Hube B, Naglik JR (2016) Candidalysin is a fungal peptide toxin critical for mucosal infection. Nature 532(7597): 64-68. doi: 10.1038/nature17625

65. Tumbarello M, Fiori B, Trecarichi EM, Posteraro $P$, Losito AR, De Luca A, Sanguinetti M, Fadda G, Cauda R, Posteraro B (2012). Risk factors and outcomes of candidemia caused by biofilm-forming isolates in a tertiary care hospital. PLoS One 7(3): e33705. doi: 10.1371/journal.pone.0033705

66. Alonso MF, Gow NAR, Erwig LP, Bain JM (2017). Macrophage Migration Is Impaired within Candida albicans Biofilms. J Fungi 3(3): E31. doi: 10.3390/jof3030031

67. Tan Y, Leonhard M, Ma S, Schneider-Stickler B (2016). Influence of culture conditions for clinically isolated non-albicans Candida biofilm formation. J Microbiol Methods 130: 123-128. doi: 10.1016/j.mimet.2016.09.011

68. Uppuluri P, Chaturvedi AK, Srinivasan A, Banerjee $M$, Ramasubramaniam AK, Kohler JR, Kadosh D, Lopez-Ribot JL (2010). Dispersion as an important step in the Candida albicans biofilm developmental cycle. PLoS Pathog 6(3): e1000828. doi: 10.1371/journal.ppat.1000828

69. Pfaller MA, Andes DR, Diekema DJ, Horn DL, Reboli AC, Rotstein C, Franks B, Azie NE (2014). Epidemiology and outcomes of invasive candidiasis due to non-albicans species of Candida in 2,496 patients: data from the Prospective Antifungal Therapy (PATH) registry 2004 2008. PLoS One 9(7): e101510. doi: 10.1371/journal.pone.0101510

70. Papon N, Courdavault V, Clastre M, Bennett RJ (2013). Emerging and emerged pathogenic Candida species: beyond the Candida albicans paradigm. PLoS Pathog 9(9): e1003550. doi: 10.1371/journal.ppat.1003550

71. Oberoi JK, Wattal C, Goel N, Raveendran R, Datta S, Prasad K (2012). Non-albicans Candida species in blood stream infections in a tertiary care hospital at New Delhi, India. Indian J Med Res 136(6): 997-1003. PMID: 23391796

72. Goel N, Ranjan PK, Aggarwal R, Chaudhary U, Sanjeev N (2009). Emergence of nonalbicans Candida in neonatal septicemia and antifungal susceptibility: experience from a tertiary care center. J Lab Physicians 1(2): 53-55. doi: 10.4103/0974-2727.59699

73. Whibley N, Gaffen SL (2015). Beyond Candida albicans: Mechanisms of immunity to non-albicans Candida species. Cytokine 76(1): 42-52. doi: 10.1016/j.cyto.2015.07.025

74. Arendrup MC, Patterson TF (2017). Multidrug-Resistant Candida: Epidemiology, Molecular Mechanisms, and Treatment. J Infect Dis 216(suppl_3): S445-S451. doi: 10.1093/infdis/jix131.

75. Spivak ES, Hanson KE (2018). Candida auris: an Emerging Fungal Pathogen. J Clin Microbiol 56(2). doi: 10.1128/JCM.01588-17 
76. Forsberg K, Woodworth K, Walters M, Berkow EL, Jackson B, Chiller T, Vallabhaneni S (2019). Candida auris: The recent emergence of a multidrug-resistant fungal pathogen. Med Mycol 57(1): 1-12. doi: 10.1093/mmy/myy054

77. Gabaldon $T$, Carrete $L$ (2016). The birth of a deadly yeast: tracing the evolutionary emergence of virulence traits in Candida glabrata. FEMS Yeast Res 16(2): fov110. doi: 10.1093/femsyr/fov110

78. Carrete L, Ksiezopolska E, Gomez-Molero E, Angoulvant A, Bader O, Fairhead C, Gabaldon T (2019). Genome Comparisons of Candida glabrata Serial Clinical Isolates Reveal Patterns of Genetic Variation in Infecting Clonal Populations. Front Microbiol 10: 112 . doi: 10.3389/fmicb.2019.00112

79. Carrete L, Ksiezopolska E, Pegueroles C, Gomez-Molero E, Saus E, Iraola-Guzman S, Loska D, Bader O, Fairhead C, Gabaldon T (2018). Patterns of Genomic Variation in the Opportunistic Pathogen Candida glabrata Suggest the Existence of Mating and a Secondary Association with Humans. Curr Biol 28(1): 15-27 e17. doi: 10.1016/j.cub.2017.11.027

80. Gabaldon T, Fairhead C (2019). Genomes shed light on the secret life of Candida glabrata: not so asexual, not so commensal. Curr Genet 65(1): 93-98. doi: 10.1007/s00294-018-0867-z

81. Merseguel KB, Nishikaku AS, Rodrigues AM, Padovan AC, Ferreira RC, de Azevedo Melo AS, Briones MR, Colombo AL (2015). Genetic diversity of medically important and emerging Candida species causing invasive infection. BMC Infect Dis 15: 57. doi: 10.1186/s12879-015-0793-3

82. Galocha M, Pais P, Cavalheiro M, Pereira D, Viana R, Teixeira MC (2019). Divergent Approaches to Virulence in $C$. albicans and $C$. glabrata: Two Sides of the Same Coin. Int J Mol Sci 20(9): E2345. doi: 10.3390/ijms20092345

83. Pais $P$, Galocha $M$, Viana $R$, Cavalheiro $M$, Pereira $D$, Teixeira $M C$ (2019). Microevolution of the pathogenic yeasts Candida albicans and Candida glabrata during antifungal therapy and host infection. Microbial Cell 6(3): 142-159. doi: 10.15698/mic2019.03.670

84. Kumar K, Askari F, Sahu MS, Kaur R (2019). Candida glabrata: A Lot More Than Meets the Eye. Microorganisms 7(2). doi: 10.3390/microorganisms7020039

85. Timmermans B, De Las Penas A, Castano I, Van Dijck P (2018). Adhesins in Candida glabrata. J Fungi 4(2): E60. doi: 10.3390/jof4020060

86. Roetzer A, Gabaldon T, Schuller C (2011). From Saccharomyces cerevisiae to Candida glabratain a few easy steps: important adaptations for an opportunistic pathogen. FEMS Microbiol Lett 314(1): 1-9. doi: 10.1111/j.1574-6968.2010.02102.x

87. Pfaller MA, Messer SA, Jones RN, Castanheira M (2015). Antifungal susceptibilities of Candida, Cryptococcus neoformans and Aspergillus fumigatus from the Asia and Western Pacific region: data from the SENTRY antifungal surveillance program (2010-2012). J Antibiot 68(9): 556-561. doi: 10.1038/ja.2015.29

88. Pfaller MA, Jones RN, Castanheira M (2014). Regional data analysis of Candida non-albicans strains collected in United States medical sites over a 6-year period, 2006-2011. Mycoses 57(10): 602-611. doi: 10.1111/myc.12206

89. d'Enfert C, Janbon G (2016). Biofilm formation in Candida glabrata: What have we learnt from functional genomics approaches? FEMS Yeast Res 16(1): fov111. doi: 10.1093/femsyr/fov111

90. Nash EE, Peters BM, Lilly EA, Noverr MC, Fidel PL, Jr. (2016). A Murine Model of Candida glabrata Vaginitis Shows No Evidence of an Inflammatory Immunopathogenic Response. PLoS One 11(1): e0147969. doi: 10.1371/journal.pone.0147969
91. Cavalheiro M, Teixeira MC (2018). Candida Biofilms: Threats, Challenges, and Promising Strategies. Front Med 5: 28. doi: 10.3389/fmed.2018.00028

92. Olson ML, Jayaraman A, Kao KC (2018). Relative Abundances of Candida albicans and Candida glabrata in In Vitro Coculture Biofilms Impact Biofilm Structure and Formation. Appl Environ Microbiol 84(8): e02769-17. doi: 10.1128/AEM.02769-17

93. Tati S, Davidow P, McCall A, Hwang-Wong E, Rojas IG, Cormack B, Edgerton M (2016). Candida glabrata Binding to Candida albicans Hyphae Enables Its Development in Oropharyngeal Candidiasis. PLoS Pathog 12(3): e1005522. doi: 10.1371/journal.ppat.1005522

94. Negri M, Silva S, Henriques M, Oliveira R (2012). Insights into Candida tropicalis nosocomial infections and virulence factors. Eur Clin Microbiol Infect Dis 31(7): 1399-1412. doi: 10.1007/s10096-0111455-z

95. Allison DL, Willems HM, Jayatilake JA, Bruno VM, Peters BM, Shirtliff ME (2016). Candida-Bacteria Interactions: Their Impact on Human Disease. Microbiol Spectr 4(3). doi 10.1128/microbiolspec.VMBF-0030-2016

96. Gaydos CA, Beqaj S, Schwebke JR, Lebed J, Smith B, Davis TE, Fife KH, Nyirjesy P, Spurrell T, Furgerson D, Coleman J, Paradis S, Cooper CK (2017). Clinical Validation of a Test for the Diagnosis of Vaginitis. $\begin{array}{lll}\text { Obstet } \quad \text { Gynecol 130(1): 181-189. } & \end{array}$ 10.1097/AOG.0000000000002090

97. Brown GD, Denning DW, Gow NA, Levitz SM, Netea MG, White TC (2012). Hidden killers: human fungal infections. Sci Transl Med 4(165): 165rv113. doi: 10.1126/scitranslmed.3004404

98. Mouafo TH, Mbawala A, Ndjouenkeu R (2018). Effect of Different Carbon Sources on Biosurfactants' Production by Three Strains of Lactobacillus spp. Biomed Res Int 2018: 5034783. doi: $10.1155 / 2018 / 5034783$

99. Pfaller MA, Rhomberg PR, Messer SA, Jones RN, Castanheira M (2015). Isavuconazole, micafungin, and 8 comparator antifungal agents' susceptibility profiles for common and uncommon opportunistic fungi collected in 2013: temporal analysis of antifungal drug resistance using CLSI species-specific clinical breakpoints and proposed epidemiological cutoff values. Diagn Microbiol Infect Dis 82(4): 303-313. doi: 10.1016/j.diagmicrobio.2015.04.008

100. Sobel JD, Chaim W, Nagappan V, Leaman D (2003). Treatment of vaginitis caused by Candida glabrata: use of topical boric acid and flucytosine. Am J Obstet Gynecol 189(5): 1297-1300. doi: 10.1067/s0002-9378(03)00726-9

101. Owen DH, Katz DF (1999). A vaginal fluid simulant. Contraception 59(2): 91-95. doi: 10.1016/s0010-7824(99)00010-4

102. Chaudry AN, Travers PJ, Yuenger J, Colletta L, Evans P, Zenilman JM, Tummon A (2004). Analysis of vaginal acetic acid in patients undergoing treatment for bacterial vaginosis. J Clin Microbiol 42(11): 5170-5175. doi: 10.1128/JCM.42.11.5170-5175.2004

103. Juarez Tomas MS, Saralegui Duhart $\mathrm{Cl}$, De Gregorio PR, Vera Pingitore E, Nader-Macias ME (2011). Urogenital pathogen inhibition and compatibility between vaginal Lactobacillus strains to be considered as probiotic candidates. Eur J Obstet Gynecol Reprod Biol 159(2): 399-406. doi: 10.1016/j.ejogrb.2011.07.010

104. O'Hanlon DE, Moench TR, Cone RA (2013). Vaginal pH and microbicidal lactic acid when lactobacilli dominate the microbiota. PLoS One 8(11): e80074. doi: 10.1371/journal.pone.0080074

105. Kohler GA, Assefa S, Reid G (2012). Probiotic interference of Lactobacillus rhamnosus GR-1 and Lactobacillus reuteri RC-14 with the opportunistic fungal pathogen Candida albicans. Infect Dis Obstet Gynecol 2012: 636474. doi: 10.1155/2012/636474 
106. Song YG, Lee SH (2017). Inhibitory effects of Lactobacillus rhamnosus and Lactobacillus casei on Candida biofilm of denture surface. Arch Oral Biol 76: 1-6. doi: 10.1016/j.archoralbio.2016.12.014

107. Chew SY, Cheah YK, Seow HF, Sandai D, Than LT (2015). In vitro modulation of probiotic bacteria on the biofilm of Candida glabrata. Anaerobe 34: 132-138. doi: 10.1016/j.anaerobe.2015.05.009

108. Liu MB, Xu SR, He Y, Deng GH, Sheng HF, Huang XM, Ouyang $C Y$, Zhou HW (2013). Diverse vaginal microbiomes in reproductive-age women with vulvovaginal candidiasis. PLoS One 8(11): e79812. doi: 10.1371/journal.pone.0079812

109. Mijac VD, Dukic SV, Opavski NZ, Dukic MK, Ranin LT (2006). Hydrogen peroxide producing lactobacilli in women with vaginal infections. Eur J Obstet Gynecol Reprod Biol 129(1): 69-76. doi: 10.1016/j.ejogrb.2005.11.036

110. Sobel JD, Chaim W (1996). Vaginal microbiology of women with acute recurrent vulvovaginal candidiasis. J Clin Microbiol 34(10): 2497-2499. PMID: 8880507

111. Cottier F, Tan AS, Chen J, Lum J, Zolezzi F, Poidinger M, Pavelka N (2015). The transcriptional stress response of Candida albicans to weak organic acids. G3 5(4): 497-505. doi: 10.1534/g3.114.015941

112. Cottier F, Tan AS, Xu X, Wang Y, Pavelka N (2015). MIG1 Regulates Resistance of Candida albicans against the Fungistatic Effect of Weak Organic Acids. Eukaryot Cell 14(10): 1054-1061. doi: 10.1128/EC.00129-15

113. Ene IV, Cheng SC, Netea MG, Brown AJ (2013). Growth of Candida albicans cells on the physiologically relevant carbon source lactate affects their recognition and phagocytosis by immune cells. Infect Immun 81(1): 238-248. doi: 10.1128/IAI.01092-12

114. Ramsdale M, Selway L, Stead D, Walker J, Yin Z, Nicholls SM, Crowe J, Sheils EM, Brown AJ (2008). MNL1 regulates weak acidinduced stress responses of the fungal pathogen Candida albicans. Mol Biol Cell 19(10): 4393-4403. doi: 10.1091/mbc.E07-09-0946

115. Schuller C, Mamnun YM, Mollapour M, Krapf G, Schuster M, Bauer BE, Piper PW, Kuchler K (2004). Global phenotypic analysis and transcriptional profiling defines the weak acid stress response regulon in Saccharomyces cerevisiae. Mol Biol Cell 15(2): 706-720. doi: 10.1091/mbc.e03-05-0322

116. Jandric Z, Gregori C, Klopf E, Radolf M, Schuller C (2013). Sorbic acid stress activates the Candida glabrata high osmolarity glycerol MAP kinase pathway. Front Microbiol 4: 350 . doi: 10.3389/fmicb.2013.00350

117. Kawahata M, Masaki K, Fujii T, lefuji H (2006). Yeast genes involved in response to lactic acid and acetic acid: acidic conditions caused by the organic acids in Saccharomyces cerevisiae cultures induce expression of intracellular metal metabolism genes regulated by Aft1p. FEMS Yeast Res 6(6): 924-936. doi: 10.1111/j.15671364.2006.00089.x

118. Beyer R, Jandric Z, Zutz C, Gregori C, Willinger B, Jacobsen ID, Kovarik P, Strauss J, Schuller C (2018). Competition of Candida glabrata against Lactobacillus is Hog1 dependent. Cell Microbiol 20(12): e12943. doi: 10.1111/cmi.12943

119. Mira NP, Teixeira MC, Sa-Correia I (2010). Adaptive response and tolerance to weak acids in Saccharomyces cerevisiae: a genome-wide view. OMICS 14(5): 525-540. doi: 10.1089/omi.2010.0072

120. de Barros PP, Scorzoni L, Ribeiro FC, Fugisaki LRO, Fuchs BB, Mylonakis E, Jorge AOC, Junqueira JC, Rossoni RD (2018). Lactobacillus paracasei 28.4 reduces in vitro hyphae formation of Candida albicans and prevents the filamentation in an experimental model of Caenorhabditis elegans. Microb Pathog 117: 80-87. doi: 10.1016/j.micpath.2018.02.019
121. Ene IV, Heilmann CJ, Sorgo AG, Walker LA, de Koster CG, Munro CA, Klis FM, Brown AJ (2012). Carbon source-induced reprogramming of the cell wall proteome and secretome modulates the adherence and drug resistance of the fungal pathogen Candida albicans. Proteomics 12(21): 3164-3179. doi: 10.1002/pmic. 201200228

122. Willems HM, Kos K, Jabra-Rizk MA, Krom BP (2016). Candida albicans in oral biofilms could prevent caries. Pathog Dis 74(5): ftw039. doi: 10.1093/femspd/ftw039

123. Aarti C, Khusro A, Varghese R, Arasu MV, Agastian P, Al-Dhabi NA llavenil S, Choi KC (2018). In vitro investigation on probiotic, antiCandida, and antibiofilm properties of Lactobacillus pentosus strain LAP1. Arch Oral Biol 89: 99-106. doi 10.1016/j.archoralbio.2018.02.014

124. Aarti C, Khusro A, Arasu MV, Agastian P, Al-Dhabi NA (2016). Biological potency and characterization of antibacterial substances produced by Lactobacillus pentosus isolated from Hentak, a fermented fish product of North-East India. Springerplus 5(1): 1743. doi: 10.1186/s40064-016-3452-2

125. Parolin C, Marangoni A, Laghi L, Foschi C, Nahui Palomino RA, Calonghi N, Cevenini R, Vitali B (2015). Isolation of Vaginal Lactobacilli and Characterization of Anti-Candida Activity. PLoS One 10(6): e0131220. doi: 10.1371/journal.pone.0131220

126. Eschenbach DA, Davick PR, Williams BL, Klebanoff SJ, YoungSmith K, Critchlow CM, Holmes KK (1989). Prevalence of hydrogen peroxide-producing Lactobacillus species in normal women and women with bacterial vaginosis. J Clin Microbiol 27(2): 251-256. PMID: 2915019

127. Roetzer A, Klopf E, Gratz N, Marcet-Houben M, Hiller E, Rupp S Gabaldon T, Kovarik P, Schuller C (2011). Regulation of Candida glabrata oxidative stress resistance is adapted to host environment FEBS Lett 585(2): 319-327. doi: 10.1016/j.febslet.2010.12.006

128. O'Hanlon DE, Moench TR, Cone RA (2011). In vaginal fluid, bacteria associated with bacterial vaginosis can be suppressed with lactic acid but not hydrogen peroxide. BMC Infect Dis 11: 200. doi: 10.1186/1471-2334-11-200

129. Peleg AY, Hogan DA, Mylonakis E (2010). Medically important bacterial-fungal interactions. Nat Rev Microbiol 8(5): 340-349. doi: 10.1038/nrmicro2313

130. Rodrigues L, Banat IM, Teixeira J, Oliveira R (2006). Biosurfactants: potential applications in medicine. J Antimicrob Chemother 57(4): 609-618. doi: 10.1093/jac/dkl024

131. King RD, Lee JC, Morris AL (1980). Adherence of Candida albicans and other Candida species to mucosal epithelial cells. Infect Immun 27(2): 667-674. PMID: 6991423

132. Atanasova R, Angoulvant A, Tefit M, Gay F, Guitard J, Mazier D, Fairhead C, Hennequin C (2013). A mouse model for Candida glabrata hematogenous disseminated infection starting from the gut: evaluation of strains with different adhesion properties. PLoS One 8(7): e69664. doi: 10.1371/journal.pone.0069664

133. Satpute SK, Kulkarni GR, Banpurkar AG, Banat IM, Mone NS, Patil $\mathrm{RH}$, Cameotra SS (2016). Biosurfactant/s from Lactobacilli species: Properties, challenges and potential biomedical applications. J Basic Microbiol 56(11): 1140-1158. doi: 10.1002/jobm.201600143

134. Ceresa C, Tessarolo F, Caola I, Nollo G, Cavallo M, Rinaldi M Fracchia L (2015). Inhibition of Candida albicans adhesion on medicalgrade silicone by a Lactobacillus-derived biosurfactant. J Appl Microbiol 118(5): 1116-1125. doi: 10.1111/jam.12760

135. Rossoni RD, de Barros PP, de Alvarenga JA, Ribeiro FC, Velloso MDS, Fuchs BB, Mylonakis E, Jorge AOC, Junqueira JC (2018). Antifungal activity of clinical Lactobacillus strains against Candida albicans biofilms: identification of potential probiotic candidates to 
prevent oral candidiasis. Biofouling 34(2): 212-225. doi: 10.1080/08927014.2018.1425402

136. Mailander-Sanchez D, Braunsdorf C, Grumaz C, Muller C, Lorenz $S$, Stevens P, Wagener J, Hebecker B, Hube B, Bracher F, Sohn K, Schaller $M$ (2017). Antifungal defense of probiotic Lactobacillus rhamnosus GG is mediated by blocking adhesion and nutrient depletion. PLoS One 12(10): e0184438. doi: 10.1371/journal.pone.0184438

137. Niu XX, Li T, Zhang X, Wang SX, Liu ZH (2017). Lactobacillus crispatus Modulates Vaginal Epithelial Cell Innate Response to Candida albicans. Chin Med J 130(3): 273-279. doi: 10.4103/03666999.198927

138. James KM, MacDonald KW, Chanyi RM, Cadieux PA, Burton JP (2016). Inhibition of Candida albicans biofilm formation and modulation of gene expression by probiotic cells and supernatant. J Med Microbiol 65(4): 328-336. doi: 10.1099/jmm.0.000226

139. Stoldt VR, Sonneborn A, Leuker CE, Ernst JF (1997). Efg1p, an essential regulator of morphogenesis of the human pathogen Candida albicans, is a member of a conserved class of bHLH proteins regulating morphogenetic processes in fungi. EMBO J 16(8): 1982-1991. doi: 10.1093/emboj/16.8.1982

140. Sharkey LL, McNemar MD, Saporito-Irwin SM, Sypherd PS, Fonzi WA (1999). HWP1 functions in the morphological development of Candida albicans downstream of EFG1, TUP1, and RBF1. J Bacteriol181(17): 5273-5279. PMID: 10464197

141. Calderon J, Zavrel M, Ragni E, Fonzi WA, Rupp S, Popolo L (2010). PHR1, a pH-regulated gene of Candida albicans encoding a glucanremodelling enzyme, is required for adhesion and invasion. Microbiology 156(Pt 8): 2484-2494. doi: 10.1099/mic.0.038000-0

142. Iraqui I, Garcia-Sanchez S, Aubert S, Dromer F, Ghigo JM, d'Enfert $C$, Janbon $\mathrm{G}$ (2005). The Yak1p kinase controls expression of adhesins and biofilm formation in Candida glabrata in a Sir4p-dependent pathway. Mol Microbiol 55(4): 1259-1271. doi: 10.1111/j.13652958.2004.04475.x

143. Bourgeois C, Kuchler K (2012). Fungal pathogens-a sweet and sour treat for toll-like receptors. Front Cell Infect Microbiol 2: 142 doi: 10.3389/fcimb.2012.00142

144. Wirnsberger G, Zwolanek F, Asaoka T, Kozieradzki I, Tortola L, Wimmer RA, Kavirayani A, Fresser F, Baier G, Langdon WY, Ikeda F, Kuchler K, Penninger JM (2016). Inhibition of CBLB protects from lethal Candida albicans sepsis. Nat Med 22(8): 915-923. doi: $10.1038 / \mathrm{nm} .4134$

145. Verma A, Gaffen SL, Swidergall M (2017). Innate Immunity to Mucosal Candida Infections. J Fungi 3(4): E60. doi: 10.3390/jof3040060

146. Romani L (1999). Immunity to Candida albicans: Th1, Th2 cells and beyond. Curr Opin Microbiol 2(4): 363-367. doi: 10.1016/S13695274(99)80064-2

147. Clemons KV, Stevens DA (2001). Overview of host defense mechanisms in systemic mycoses and the basis for immunotherapy. Semin Respir Infect 16(1): 60-66. doi: 10.1053/srin.2001.22729

148. Savolainen J, Rantala A, Nermes M, Lehtonen L, Viander M (1996) Enhanced IgE response to Candida albicans in postoperative invasive candidiasis. Clin Exp Allergy 26(4): 452-460. doi: 10.1046/j.13652222.1996.d01-330.x

149. Hamad M (2012). Innate and adaptive antifungal immune responses: partners on an equal footing. Mycoses 55(3): 205-217. doi: 10.1111/j.1439-0507.2011.02078.x

150. Saito S, Nakashima A, Shima T, Ito M (2010). Th1/Th2/Th17 and regulatory T-cell paradigm in pregnancy. Am J Reprod Immunol 63(6): 601-610. doi: 10.1111/j.1600-0897.2010.00852.x
151. Webb LM, Lundie RJ, Borger JG, Brown SL, Connor LM, Cartwright AN, Dougall AM, Wilbers RH, Cook PC, Jackson-Jones LH, PhythianAdams AT, Johansson C, Davis DM, Dewals BG, Ronchese F, MacDonald AS (2017). Type I interferon is required for T helper (Th) 2 induction by dendritic cells. EMBO J 36(16): 2404-2418. doi: 10.15252/embj.201695345

152. Majer O, Bourgeois C, Zwolanek F, Lassnig C, Kerjaschki D, Mack M, Muller M, Kuchler K (2012). Type I interferons promote fatal immunopathology by regulating inflammatory monocytes and neutrophils during Candida infections. PLoS Pathog 8(7): e1002811. doi: 10.1371/journal.ppat.1002811

153. van der Graaf CA, Netea MG, Verschueren I, van der Meer JW, Kullberg BJ (2005). Differential cytokine production and Toll-like receptor signaling pathways by Candida albicans blastoconidia and hyphae. Infect Immun 73(11): 7458-7464. doi: 10.1128/IAI.73.11.7458-7464.2005

154. Vazquez-Torres A, Jones-Carson J, Wagner RD, Warner T, Balish E (1999). Early resistance of interleukin-10 knockout mice to acute systemic candidiasis. Infect Immun 67(2): 670-674. PMID: 9916075

155. Netea MG, Sutmuller R, Hermann C, Van der Graaf CA, Van der Meer JW, van Krieken JH, Hartung T, Adema G, Kullberg BJ (2004). Toll-like receptor 2 suppresses immunity against Candida albicans through induction of IL-10 and regulatory T cells. J Immunol 172(6): 3712-3718. doi: 10.4049/jimmunol.172.6.3712

156. Santos CMA, Pires MCV, Leao TL, Hernandez ZP, Rodriguez ML, Martins AKS, Miranda LS, Martins FS, Nicoli JR (2016). Selection of Lactobacillus strains as potential probiotics for vaginitis treatment. Microbiol-Sgm 162: 1195-1207. doi: 10.1099/mic.0.000302

157. Eversole LR, Reichart PA, Ficarra G, Schmidt-Westhausen A, Romagnoli P, Pimpinelli N (1997). Oral keratinocyte immune responses in HIV-associated candidiasis. Oral Surg Oral Med Oral Pathol Oral Radiol Endod 84(4): 372-380. doi: 10.1016/s10792104(97)90035-4

158. Santos CMA, Pires MCV, Leao TL, Silva AKS, Miranda LS, Martins FS, Silva AM, Nicoli JR (2018). Anti-inflammatory effect of two Lactobacillus strains during infection with Gardnerella vaginalis and Candida albicans in a HeLa cell culture model. Microbiology 164(3): 349-358. doi: 10.1099/mic.0.000608

159. Pietrella $D$, Rachini A, Pines $M$, Pandey N, Mosci P, Bistoni $F$ d'Enfert C, Vecchiarelli A (2011). Th17 cells and IL-17 in protective immunity to vaginal candidiasis. PLoS One 6(7): e22770. doi: 10.1371/journal.pone.0022770

160. Yano J, Kolls JK, Happel KI, Wormley F, Wozniak KL, Fidel PL, Jr. (2012). The acute neutrophil response mediated by $S 100$ alarmins during vaginal Candida infections is independent of the Th17-pathway. PLoS One 7(9): e46311. doi: 10.1371/journal.pone.0046311

161. Korzeniewski C, Callewaert DM (1983). An enzyme-release assay for natural cytotoxicity. J Immunol Methods 64(3): 313-320. doi: 10.1016/0022-1759(83)90438-6

162. Zelante T, lannitti RG, Cunha C, De Luca A, Giovannini G, Pieraccini G, Zecchi R, D'Angelo C, Massi-Benedetti C, Fallarino F, Carvalho A, Puccetti P, Romani L (2013). Tryptophan catabolites from microbiota engage aryl hydrocarbon receptor and balance mucosal reactivity via interleukin-22. Immunity 39(2): 372-385. doi 10.1016/j.immuni.2013.08.003

163. De Luca A, Carvalho A, Cunha C, lannitti RG, Pitzurra L, Giovannini G, Mencacci A, Bartolommei L, Moretti S, Massi-Benedetti C, Fuchs D, De Bernardis F, Puccetti P, Romani L (2013). IL-22 and IDO1 affect immunity and tolerance to murine and human vaginal candidiasis. PLoS Pathog 9(7): e1003486. doi: 10.1371/journal.ppat.1003486 
164. Seider K, Brunke S, Schild L, Jablonowski N, Wilson D, Majer O, Barz D, Haas A, Kuchler K, Schaller M, Hube B (2011). The facultative intracellular pathogen Candida glabrata subverts macrophage cytokine production and phagolysosome maturation. J Immunol 187(6): 3072-3086. doi: 10.4049/jimmunol.1003730
165. Hearps AC, Tyssen D, Srbinovski D, Bayigga L, Diaz DJD, Aldunate M, Cone RA, Gugasyan R, Anderson DJ, Tachedjian G (2017). Vaginal lactic acid elicits an anti-inflammatory response from human cervicovaginal epithelial cells and inhibits production of proinflammatory mediators associated with HIV acquisition. Mucosal Immunol 10(6): 1480-1490. doi: 10.1038/mi.2017.27 